\title{
POST-SOCIALIST LABOR FORCE AS A COMMON-POOL RESOURCE
}

\author{
Iv. Penov* \\ Economics Department, University of Agriculture- Plovdiv, Bulgaria
}

\begin{abstract}
The article is devoted to the challenges of the labour market in the post-socialist period. It discusses the issues related to the physical properties of the post-socialists labour force and the social and legal framework in which it operates. Labor traditionally is considered to be a private good in the economic literature, possessing the properties of high excludability and rivalry. We argue that in the post-socialist period, labour looks more like a common pool resource system rather than a private good. In the absence of appropriate legal and social structures, such a system is likely to operate under the conditions of open access. In the long run, this could lead to a depletion of this resource. We argue that looking at labour in the frame of common pool resource, first we can justify better the use of the traditional instruments for intervention at the labour market, and second, this could help to develop a more efficient system for preserving and development of the labour force in the long run.
\end{abstract}

Key words: Labour, common pool resources, post-socialist period, Bulgaria

\section{INTRODUCTION}

During the transition period (after 1990) the population in Bulgaria sharply declined as a result of increased of emigration, the death rate and decreased the birth rate. According to the Chairman of the Managing Board of the Industrial Capital Association, Vassil Velev (1), $68 \%$ of Bulgarian employers face difficulties in hiring workers, while $45 \%$ of employers in the world experience such problem. Also, the wages in Bulgaria are 7-9 times lower compared to the ones in Western Europe. The explanation that is often given by employers is that labour productivity in Bulgaria is smaller compared to the one in the Western countries. A friend of mine is working in France as an electrician. A company owned by a Bulgarian person hired him. For two months he earns the same money as he would in Bulgaria, but working a whole year. The question that arises here is why my friend's productivity in France is higher compared to the one of an electrician in Bulgaria. One possible answer is that labour productivity depends not only on individual skills but also

\footnotetext{
*Correspondence to: Ivan Penov, Economics Department, University of Agriculture- Plovdiv, Bulgariap 12 Mendeleev str. Plovdiv-4000, Bulgaria,ipenov@au-plovdiv.bg, ++359898 320067
}

on the socio-economic system in which people are working.

Most of the countries in Europe have introduced a minimum wage and implementing different programs for supporting the labour force (such as Human resources operational programs of the European Union). It seems that the state is getting more and more involved in the labour markets.

Traditionally, in economic literature, labour is seen as a private good, possessing the properties of excludability and rivalry. In such a case, and under conditions of perfect competition, the market would provide an efficient level of employment and salaries. However, unemployment is a problem in many regions and countries. In other places, employers have difficulties in finding workers. Several questions could arise from the above discussion. First, if labour is a private good, why are businesses and the state involved in preserving the workforce in their area? Why do we train people in production or management and achieve the desired results? To what extent is the community important? The main question here is what kind of "good" labour is? To elaborate on these questions, first, the conventional presentation of labour is shortly reviewed, second, the concepts of types of 
goods are presented, and finally, we argue that the labour, especially in the post-socialist period, may be better understood in the framework of common pool resources rather than as a private good.

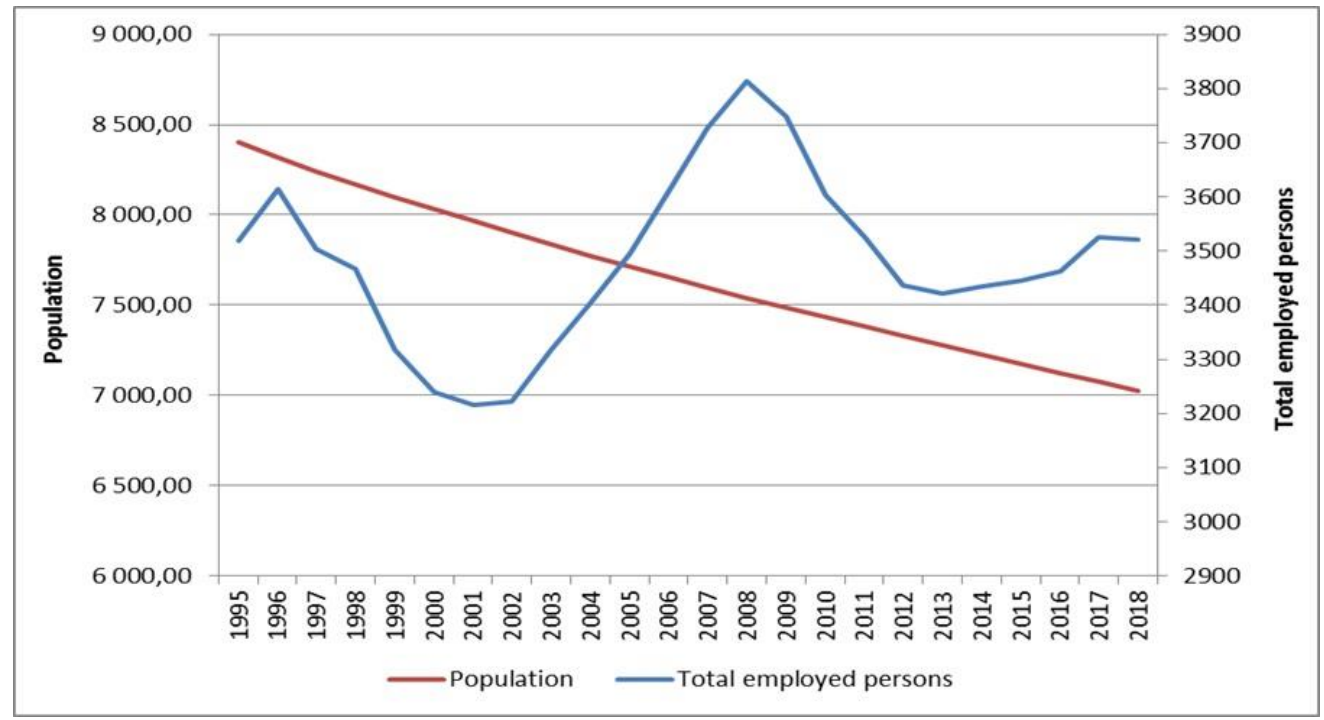

Figure 1. Population and employed people in Bulgaria 1995-2018

Source: Designed with data from NSI (2)

\section{LABOUR IN THE CONVENTIONAL ECONOMIC LITERATURE}

The issues related to labour are discussed in both the standard micro and macroeconomics textbooks. In microeconomics, the individual firm's labour demand is derived from the value of the marginal physical product of labour. The market labour demand is the sum of all firms' demands. It represents the readiness of firms to hire a different number of workers depending on the wage rate. Individual labour supply is derived from the indifference curves, expressing the trade-off between income (work) and leisure, and the budget line. The market labour supply is the sum of all individual labour supply. It expresses the willingness of the people to work, depending on the wage rate. Market supply and demand determine the equilibrium wage and employment.

The macroeconomic theory considers the personal and households' behaviour and the choice of how much to consume and save. In Keynesian theory, this choice is made in one period. Keynes assumes that consumption increases with income. In the two period's model, the question is how the households decide on their current and future consumption. This model allows moving consumption from today into the future and from the future to the current time. Macroeconomics offers several explanations of unemployment. According to the classical view, the nominal wages are flexible, and they change so that the labour market is in balance. The real wages are at the level where the market is cleared at full employment. However, if we have trade unions, collective bargaining etc., and the wages are fixed above the equilibrium and unemployment occurs. According to the Keynesian view, the nominal wages and prices are not flexible, and they are not corrected quickly enough to keep up the balance of the labour market. Demand for labour is determined not by the labour costs, but by demand for goods and services. Therefore, employment depends more on the behaviour of companies than on the behaviour of workers.

Political economists make a distinction between the exchange value and the use value of goods. The use value is a property of product to satisfy some human needs (Cohen G.A. 1979 (3), Whitaker, C. A. B., 1904 (4), Saad-Filho A. 2012 (5). The exchange value is a property of a product of having use value for other people, not to the ones that produced them. According to Marx, the use value of labour power is to create more value of its exchange value.

Generally, what these theories are telling is what happens with labour when it is there. They do not provide enough inside about how the labour acquires the needed characteristics.

\section{COMMON POOL RESOURCES}

The distinction between the different types of goods is made considering two physical 
characteristics: rivalry and excludability. Rivalry means that if a good is used by one consumer, the same good cannot be used by other consumers. Excludability is the possibility to prevent people who do not pay to have access to a good. These physical characteristics of goods are a factor for determining the property rights regime in which they can be produced or/and traded efficiently. The property rights regimes can take different forms: open access; private ownership, state ownership, collective property rights regimes, etc. (Theesfeld, 2019 (6).
Pure private goods are rival and excludable. In this case, the market is the most efficient mechanism to determine the price and quantity needed. Pure public goods are non-rival and non-excludable. In this case, the free-riders problem occurs, and the market cannot efficiently provide them (market provides less compared to what is efficient for the economic system). That is why public goods are often delivered the government through the political process or collectively.

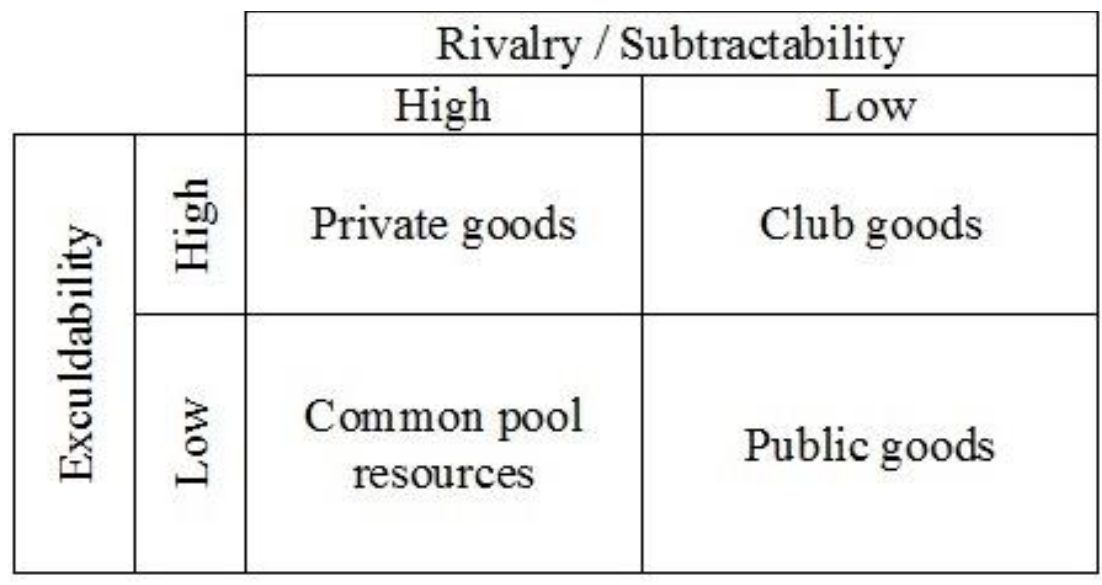

Figure 2. Maps of the goods

Source: designed from Theesfeld, I. (2005, (7)

Common pool resources are limited excludable, but rival in consumption. Most of the theoretical development in the area is related to Eleonor Ostrom. This author considers the common-pool resources not as separate goods but as a system that consists of a stock of resources and a flow of goods or benefits. Examples of stocks of resources are water in the lakes and rivers, fishery stocks, forests, grazing land. These systems provide flows of benefits or goods: water, fish, timber, forage. Because of limited excludability, they are under the threat of being overused if no particular property right regime is established. Ostrom 1994 (8), distinguishes between appropriation transactions and provision transactions related to common pool resources.

\section{COULD LABOR BE A COMMON POOL RESOURCE?}

In economic literature, labour is classified as a private good, possessing the properties of excludability and rivalry. If this is the case, the market should provide an efficient solution, and there would be no need for state intervention. However, in most countries, the state is heavily involved in the labour markets, and many workers are members of trade unions.

To elaborate on the labour physical property, first, some terminology related to population and labour force will be defined. The population is the number of people in a given area. Fertility is the number of children born during a given period (year). Mortality is the number of deaths during a given period (year). Immigrants are people that move into the area to settle there but are not natives. Emigrants are people that leave the area to settle elsewhere.

Employment seems like a relationship between employees and employers. Employees received a salary for the work they do. The employers sell the goods or services produced by the employees and earn profit for the capital they invested and for organising the production process. However, what the employers need is not workers, but their skills to produce. The physical carriers of this quality are the people. In this respect, we could consider the available labourer as a stock of resources that could provide the flow of benefits (skills to produce) to the firms. The newly born and immigrants potentially (after going through the social and 
educational system) are adding, and mortality and the emigrants are subtracting from this stock.

Table 1. Population and employment in Bulgaria 2010-2017 (in thousands)

\begin{tabular}{|l|c|c|c|c|c|c|c|c|c|}
\hline & $\mathbf{2 0 1 0}$ & $\mathbf{2 0 1 1}$ & $\mathbf{2 0 1 2}$ & $\mathbf{2 0 1 3}$ & $\mathbf{2 0 1 4}$ & $\mathbf{2 0 1 5}$ & $\mathbf{2 0 1 6}$ & $\mathbf{2 0 1 7}$ & $\mathbf{2 0 1 8}$ \\
\hline Population & 7505 & 7327 & 7285 & 7246 & 7202 & 7154 & 7102 & 7050 & 7000 \\
\hline Internal growth \\
\hline Fertility & 76 & 71 & 70 & 67 & 68 & 66 & 65 & 64 & 63 \\
\hline Mortality & 110 & 108 & 109 & 104 & 109 & 110 & 108 & 110 & 109 \\
\hline Migration & 4 & 5 & 14 & 19 & 27 & 25 & 21 & 26 & 30 \\
\hline Immigrants & 28 & 10 & 17 & 20 & 29 & 29 & 31 & 32 & 33 \\
\hline Emigrants & \multicolumn{7}{|l|}{$\mid$} \\
\hline Structure of the population \\
\hline $\begin{array}{l}\text { Under working } \\
\text { age }\end{array}$ & 1098 & 1045 & 1048 & 1056 & 1065 & 1064 & 1063 & 1066 & 1067 \\
\hline In working age & 4701 & 4523 & 4505 & 4472 & 4403 & 4349 & 4304 & 4249 & 4201 \\
\hline Over working age & 1706 & 1760 & 1731 & 1718 & 1734 & 1741 & 1735 & 1736 & 1732 \\
\hline Employed persons & & & & & & & \\
\hline Total & 3604 & 3525 & 3436 & 3422 & 3434 & 3446 & 3463 & 3525 & 3522 \\
\hline $\begin{array}{l}\text { Employed } \\
\text { persons }\end{array}$ & 2628 & 2587 & 2540 & 2511 & 2506 & 2531 & 2576 & 2584 & 2606 \\
\hline \begin{tabular}{l} 
Self-employed \\
\hline
\end{tabular} & 976 & 938 & 897 & 911 & 928 & 915 & 887 & 941 & 916 \\
\hline
\end{tabular}

Source: designed with data from NSI (2)

The ability to produce includes not only the professional skills of workers but also their values, believes, general knowledge, health condition, etc. The professional qualifications can be acquired in a comparatively shorter time through the system of vocational training. The qualities such as moral norms, discipline, conscience, empathy, etc. are essential for the practical application of professional skills in the existing economic system. They can be acquired in a more extended time. The role of the family, community, culture, general training at school is indispensable here. They may be considered as a fixed cost, which can be very high and sometimes difficult to measure.

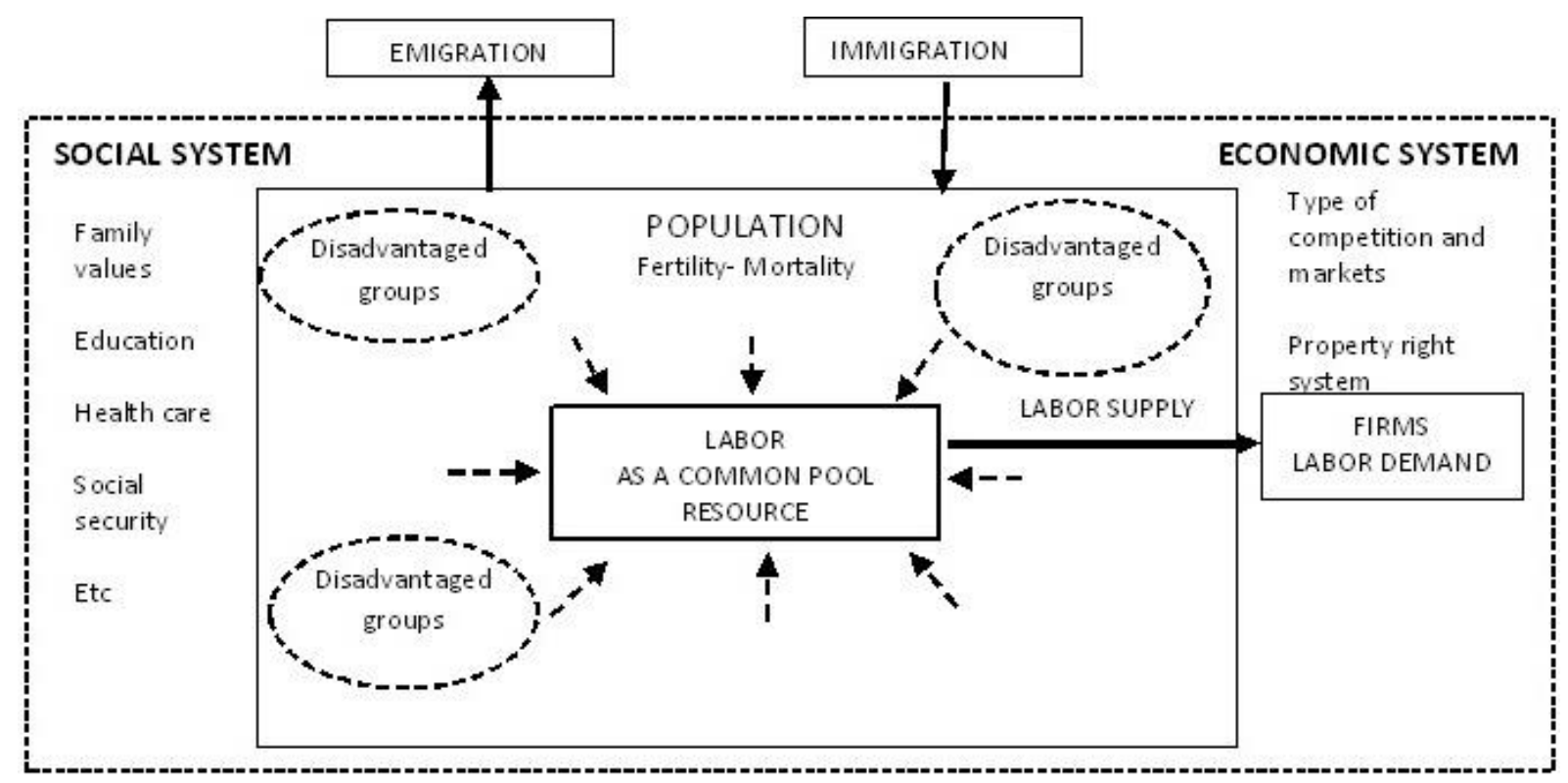

Source: own presentation

Figure 3. Labor as a common pool resource 
The rivalry is comparatively apparent in the case of labour. If a worker is hired or his labour force is used by one employer, this prevents other employers from using it at the same time. The excludability, however, may be disputable. At a personal level, as Walker 2019 (9) summarised the discussions for this issue, a worker can refuse an offer for a job, but he cannot deny it forever, especially if he does not have other sources of income. As a result, workers can exclude themselves in the short run, but not in the long run. On the national level if workers cannot exit the economic system (emigrate), or their opportunities to start their own business are limited, etc. they have to accept at some point of time jobs offered in this system. The existence of the organisations that protect workers interest increases the opportunities to resist job offers that they are not willing to take.

Workers are part of the population, and they are the physical carriers of the labour force. The "production" of workers and labour force happens in the communities and therefore, collectively. Thus, in the case of labour, we may think for the provision transactions as related to increasing or stabilising the population, acquiring the moral norm and skills necessary for the labour force, and about the appropriations transactions as associated with the organisation of the labour market were supply and demand meet.

\section{FACTORS INFLUENCING THE EMPLOYMENT AND EXCLUDABILITY}

Trade unions are essential institutions for the labour markets. Hired workers need protection, but also the employers need an intermediary in resolving labour disputes. The trade union members in Bulgaria had been decreasing over the past 20 years, and it is unclear to what extent they represent the labour force (Ganev 2018, (10)). According to Goranova 2010 (11), due to inertia from socialism, the state enterprises are the last resting place of the trade unions in Bulgaria, and the privatisation would further weaken them. This author predicts that with the increase in unemployment, social protests would multiply and spontaneously organised interest groups would lead them. Many protesters would not be members of trade unions. Further, the author states that Bulgarian civil society was changing slowly, new leaders, self-organising communities, appear and the trade unions may burn in the rebellion fire.

Table 2. Trade union member 1993-2003

\begin{tabular}{|l|c|c|c|c|}
\hline Trade union & 1993 & 1998 & 2003 & $\begin{array}{c}\text { Share to all } \\
\text { employed people } \\
2003\end{array}$ \\
\hline КНСБ & 1426000 & 608000 & 390000 & $13.8 \%$ \\
\hline Podkrepa & 500000 & 155000 & 109000 & $3.9 \%$ \\
\hline Change & - & 8000 & 5000 & $0.2 \%$ \\
\hline Others & 266000 & 7000 & 11000 & $0.4 \%$ \\
\hline Общо & 2192000 & 778000 & 515000 & $18 \%$ \\
\hline
\end{tabular}

Source: IME. https://ime.bg/bg/articles/sindikatite-w-bylgariq-ne-w-tozi-format/\#ixzz5nEQR3HVy

Theesfeld 2019 (6), distinguishes four periods in changing the formal and informal rules and their enforcement mechanisms in the former socialists' countries: (1) pre-revolutionary ; (2) revolutionary (after 1990); (3) postrevolutionary; and (4) evolutionary (after EU accession). According to this author during the post-revolutionary periods, following pressures for reforms and more self-governance a considerable discrepancy exists between formal and informal rules, resulting in pseudoimplementation of reforms. The results are either top-down management or an openaccess situation with some powerful actors striving for personal benefits (Theesfeld, 2004, (12).

Trade unions are essential institutions that protect labour by providing opportunities for collective bargaining. However, during the transition period, they may not be able to perform this vital function because they may need time to adapt to the new conditions.

Numerous studies investigate the relations between the social capital, human capital and labour market. However, still, there are no widely accepted definitions of these terms. Putnam $(13,14)$ defines social capital as social organisations such as networks, norms, trust 
that helps coordination and cooperation for mutual benefit. Also, he thinks for human capital as instruments and training that increase individual productivity. Fukuyama 1995 (15), defines social capital as the ability of people to work together to reach common goals.

There are no systematic studies for the links between social capital and employment in Bulgaria. However, this topic is widely researched in the case of other countries. Lancee 2010 (16), in the case of the Netherlands, Kanas, et .all. 2011 (17), in the case of Germany, Bevelander, et .all. 2009, 18), in the case of Sweden, investigated the role of social contacts for the employment status of immigrants. These authors found out that the connections within family, friends, and neighbours do not affect the employment opportunities of immigrants. However, having contacts with native increases the likelihood of employment. Sanders, et .all. 2002 (19), in the case of Asian immigrants in Los Angeles, found that the networks help the immigrants, but in getting employment in industries of low prestige, requiring low human capital. Among the reasons for this situation, these authors point out the linguistic and cultural differences of immigrants. Dustmann et .all. 2009 (20), in the case of Germany and the UK, found higher unemployment responses to economic crises for the low-skilled immigrant workers. They explain this result with the segmentation of the labour markets and the differences in the complementarity of immigrants and natives to the capital. Dietz 2010 (21), discusses the risk of using the term employment discrimination, because, immigrants differ in many dimensions from local employees. This author proposes the term differential treatment to include fair and unfair incidents of treating immigrants.

The above research shows that not only professional skills are essential for someone to be employed. The family and communal values may increase the opportunity for being hired, but also they can constrain them if these values do not coincide with the ones of the majority of the population. Therefore, important factors are not only how people are connected and interact with each other, but also the number of people sharing these values.

Raventós 2007 (22), defines the basic income as an income paid by the state to the citizens, regardless of whether they are engaged in paid employment, and independently of any other sources of income they have. This author predicts that the introduction of the basic income would favour self-employment and increase the possibility of choosing specific part-time jobs. $\mathrm{He}$ also expects that participation in voluntary activities and domestic work would increase and that would bring positive social changes.

The concept of Basic income is not an entirely new idea, but it is a quite controversial one. Nevertheless, it received more extensive attention during the past twenty years. To survive, people who do not own means of production have to sell their labour on the job market. This affects peoples' choice between employment and domestic work. One of the aims of domestic work is the reproduction of the labour force. Also, a strong argument for justifying the basic income is the decommodification of labour. Receiving guaranteed income from the State can increase the labour excludability.

The minimum wage is a price floor below which the employers cannot legally higher workers. Many countries have introduced minimum wages. There are different arguments for and against using this instrument and how it would affect the labour market. As discussed earlier, if the salary is above the equilibrium level, it will increase the level of unemployment. From this point of view, the minimum wage makes a little sense. However, if the employers have monopsony power, the minimum wage can improve the efficiency in the economy.

One of the problems with supply and demand framework is that it will produce efficient equilibrium only in the case, all costs and benefits are included in the system. If the minimum wage represents the cost that will guarantee the recovery of the labour force, and it is not a result of the supply and demand, this means that this system does not include all costs and benefits. In this case, the equilibrium that the market gives is not an efficient one.

Regarding the labour, we may think about two types of cost: short term - food lodging, etc. and long term - the cost for a person to reach maturity (or raise children) which can be very high. One of the consequences is that such a system can operate a long time, just covering the short term cost. In the long run, however, it will not be able to recover the long term cost, and it will not reproduce.

Bulgaria has the lowest minimum wage compared with the rest of the EU countries. Mancheva etc. 2017 (23), did not find evidence that the increase in the minimum wage in Bulgaria affects unemployment. 


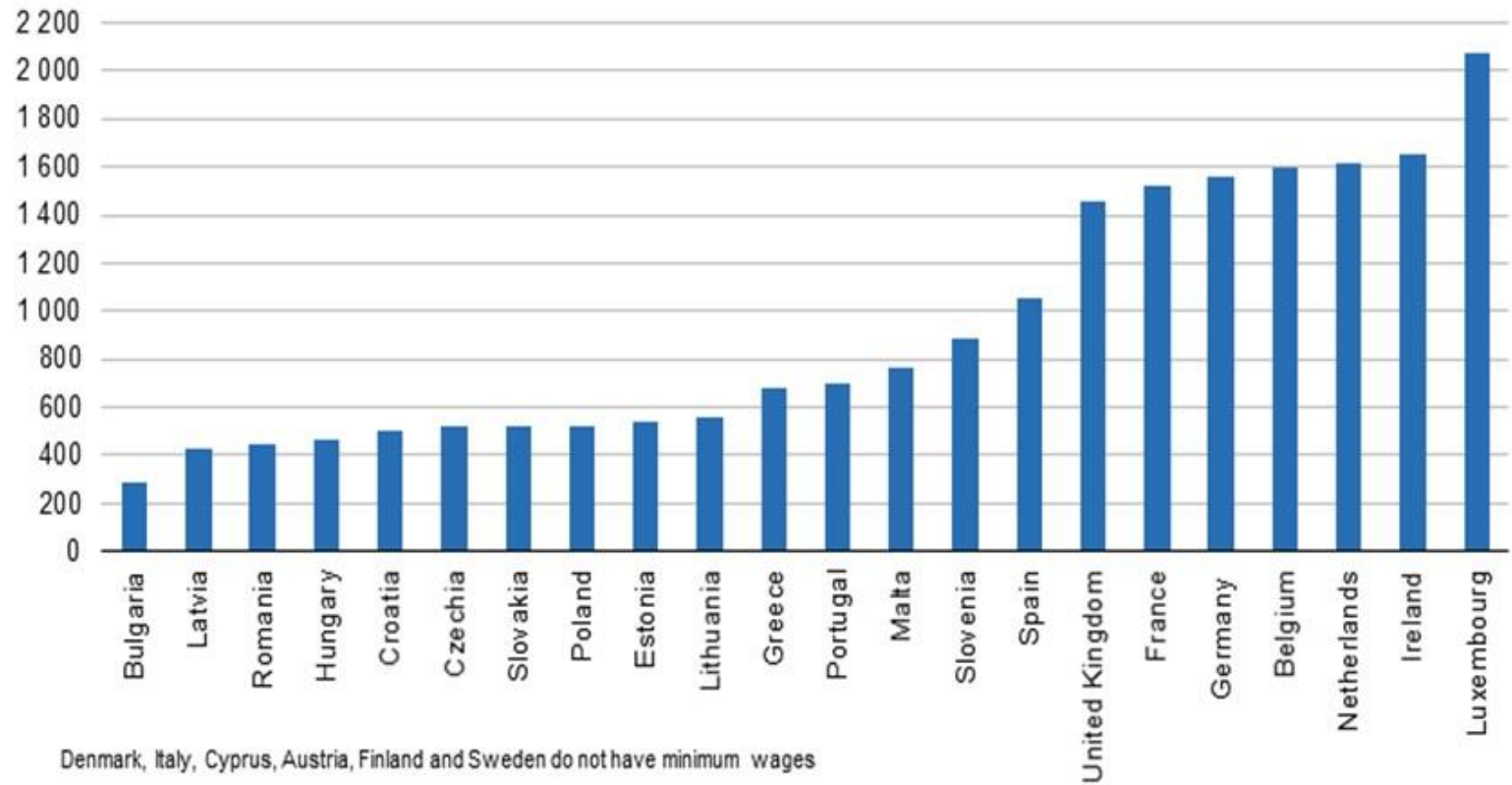

Source: Eurostat (24)

Figure 4. Minimum wages in the EU member states (euros per months) 2019

Some results for the effect of minimum wage report Ropponen 2011 (25). This author discusses the differences in the results of previous studies on fast-food restaurants in New Jersey and Pennsylvania before and after the increase of minimum wage. One of these studies argues as the theory predicts that employment decreased, but the other reported a rise in employment. Ropponen 2011 (25), found out that employment in the small restaurants had increased, but in the large one had decreased. He explained this result with the location of the restaurants. The smaller ones were located in poor areas, while the big, in areas of people with higher income. Since the income of the poor had increased, this led to an increase in the fast-food demand, and this resulted in increased employment in smaller restaurants.

The above case shows that the minimum wage can have different effects on the firms' willingness to employ workers. Generalising of what can happen on average may turn out misleading.

In economic textbooks, a clear distinction is made between households and firms. Households are the units where the consumption decisions are made. Firms are the units where the production decisions are made. However, in micro, small and medium-sized enterprises, operated by the families, often the consumption and production decisions are overlapped.

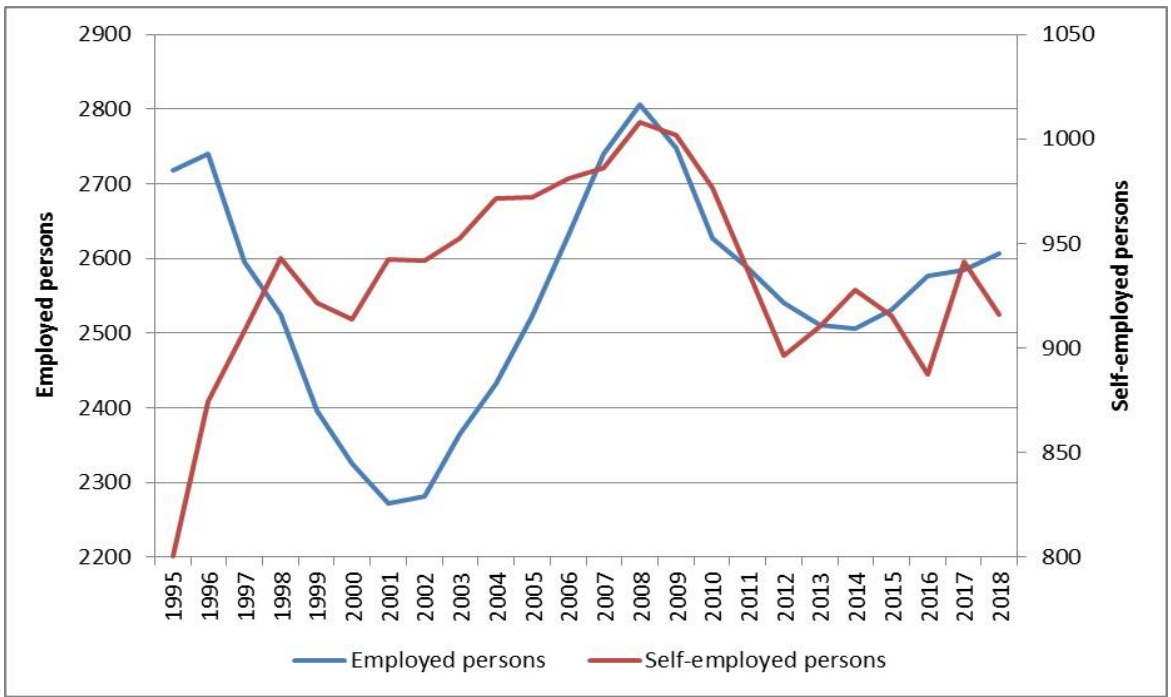

Figure 5. Employed and self-employed persons in Bulgaria 1995-1018

Source: Designed with data from NSI (2) 
According to the World Bank 2010 (26), although the business regulations in Bulgaria are not as burdensome as in many countries in the world, they are still less favourable compared with the ones of many EU countries. The main challenges outlined in this report are (1) informality and corruption; (2) low transparency in the policy-making; (3) the state fees' regime is weak, unfair, and nontransparent; (4) closing a business is costly and takes time. According to this report, the small companies face more difficulties compared to the large firms concerning access to finance and land and they are affected more by corruption and informality.

\section{CONCLUSIONS}

The article discusses the challenges facing the labour market in the post-socialist period. The issues related to the physical properties of the post-socialists labour force and the socioeconomic framework in which it operates are discussed. In economic literature, labour is considered to be a private good, possessing the properties of high excludability and rivalry. However, in the absence of the appropriate legal and social structures, the labour may have properties similar to the ones' of common pool resources operating in an open-access regime. In the long run, this could lead to depletion of the labour. Employers do not need just workers but their skills to produce. But, could we think about the labour power separate from its physical carrier - the people?

In the frame of common pool resources, the available labourer and their skills could be interpreted to be a stock of resources, which could provide flows of benefits to the firms. The provision transactions would be related to the increase or stabilising the population, development of social and human capital necessary for the labour power. The appropriations transactions would be related to the labour market were supply and demand meet.

If we think of labour in the frame of common pool resources, we can better justify the use of such instruments as minimum wage, basic income, different state programs, etc. These instruments make little sense in the simple supply and demand frame. Basic income, although a controversial concept, could be interpreted as an income support instrument. Minimum wage could be considered as an instrument to cover all cost for reproducing the labour.
The author is aware that the issue needs better justification and further discussions. It makes sense, at least in a long term macro view, to consider labour in the frame of common pool resources, which can incorporate the existing concepts regarding labour. It seems a direction that is worth investigating, at least because it is good to challenge from time to time our understanding of the well-established economic concepts.

\section{REFERENCES}

1. Velev, V., $68 \%$ ot balgarskitte rabotodateli sreshtat trudnosti pri naemane na rabotnici. Interviu s Vasil Velev predsedatel na US na Asotsiatsiyata na industrialniya kapital. Predavane "Predi vsichki". BNR, available at:

http://82.119.84.124/post/101100746/68-otbalgarskite-rabotodateli-sreshtat-trudnostipri-naemane-na-rabotnici. published at 01.04.19 in 08:19. 2019.

2. Natsionalen statisticheski institut. Statisticheski godishnik 2010-2018

3. Cohen, G.A.,The Labor Theory of Value and the Concept of Exploitation. Philosophy \& Public Affairs, 8 (4):338-360, 1979.

4. Whitaker, A., History and Criticism of the Labor Theory of Value in English Political Economy. Submitted in Partial Fulfilment of the Requirements for the Degree of Doctor of Philosophy In the Faculty of Political Science, Columbia University 1904, Kitchener 2001

5. Saad-Filho, A., Is Marx's Theory of Value Still Relevant? Available at: https://marxismocritico.files.wordpress.com /2012/09/saadfilho.pdf, 2012.

6. Theesfeld, I., Chapter 26: The role of pseudo-commons in post-socialist countries. In: Routledge handbook of the study of the commons Edited by Blake Hudson, Jonathan Rosenbloom and Dan Cole, Routledge 2019.

7. Theesfeld, I., A common pool resource in Transition. Determinants of institutional change for Bulgaria's Postsocialist irrigation sector. Ed. Beckman V. Hagedorn K. Shaker Verlang Aachen. 2005.

8. Ostrom, E., Crafting Institutions for Selfgoverning Irrigation Systems. ICS Press, Institute for Contemporary Studies, San Francisco, California, 1992.

9. Walker, T., Labour Power as a CommonPool Resource. Available at: http://wiki.p2pfoundation.net/Labour_Powe 
r_as_a_Common-Pool_Resource, Accessed 1.05.2019

10.Ganev, G., T. nar. Sotsialen dialog u nas e problemna konstruktsiya. Mediapool, Available at: https://www.mediapool.bg/georgi-ganevtnar-sotsialen-dialog-u-nas-e-problemnakonstruktsiya-news285707.html, 2018.

11.Goranova, G., V pozhara na bunta shte izgoryat I sindikatite. SEGA, Available at: http://old.segabg.com/article.php?id=45007 619 January 2010.

12.Theesfeld, I., Constraints on collective action in a transitional economy: the case of Bulgaria's irrigation sector. World Development, 32:251-271, 2004.

13.Putnam, R., Bowling Alone: America's Declining Social Capital. Journal of Democracy 6(1):65-78, Retrieved August 30, 1995

14.Putnam, R.., Bowling Alone. Simon and Schuster, New York, 2000.

15.Fukuyama, F. Trust : the social virtues and the creation of prosperity. Hamish Hamilton, London, 1995.

16.Lancee, The Economic Returns of Immigrants' Bonding and Bridging Social Capital: The Case of the Netherlands. International Migration Review, 44 (1): 202-226, 2010.

17.Kanas, A., van Tubergen, F. and van der Lippe, T., The role of social contacts in the employment status of immigrants A panel study of immigrants in Germany International Sociology, 26 (1): 95-122, 2011.

18.Bevelander, B., Pendakur, R., Citizenship, Co-ethnic Populations and Employment Probabilities of Immigrants in Sweden.
Discussion Paper No. 4495, The Institute for the Study of Labor (IZA) in Bonn, October 2009.

19.Sanders, J., Nee V.,Sernau S., Asian Immigrants' Reliance on Social Ties in a Multiethnic Labor Market. Social Forces, 81(1):281-314, 2002.

20.Dustmann, C., Glitz, A., Vogel, T., Employment, Wages, and the Economic Cycle: Differences between Immigrants and Natives. IZA Discussion Paper No. 4432. September 2009.

21.Dietz, J. Introduction to the special issue on employment discrimination against immigrants. Journal of Managerial Psychology, 25 (2):104-112, 2010.

22.Raventós, D., Basic Income. The Material Conditions Of Freedom, Pluto Press, 2007.

23.Mancheva M., Stamatev S., Tendentsii I vazdeystvie na minimalnata zaplata $\mathrm{v}$ Bulgaria sled 1999 I vliyanieto varhu ikonomicheskoto razvitie, Ikonomicheski I sotsialni alternative, 1:28-45, 2017

24.Eurostat, Disparities in minimum wages across the EU. https://ec.europa.eu/eurostat/en/web/produc ts-eurostat-news/-/DDN-20190131-2, 31/01/2019.

25.Ropponen, O., Reconciling the Evidence of Card and Krueger (1994) and Neumark and Wascher (2000). Discussion Paper No. 325 Helsinki Center of Economic Research April 2011.

26. World Bank, Bulgaria: Administrative and Regulatory Barriers to Business. International Bank for Reconstruction and Development, The World Bank. Report No. 55727-BG, 2010. 